\title{
Decision support systems for scheduling tasks in Biosystems Engineering
}

\author{
Adrian Knapczyk ${ }^{1, *}$, Stawomir Francik ${ }^{1}$, Marek Wróbel $^{1}$, Marcin Jewiarz ${ }^{1}$, \\ and Krzysztof Mudryk ${ }^{1}$ \\ ${ }^{1}$ University of Agriculture in Krakow, Faculty of Production and Power Engineering, Department of \\ Mechanical Engineering and Agrophysics, Balicka 120, 30-149 Krakow, Poland
}

\begin{abstract}
Modern decision support systems have many applications, including assistance in scheduling tasks. Biosystems engineering combines engineering sciences and physical sciences in order to understand and improve biological systems in agriculture, food production, environment, etc. The work reviews the decision support systems in the aspect of scheduling tasks in the field of biosystems engineering. The analysis was based on documents (articles and proceedings paper) indexed in the Web of Science Core Collection (WoS-CC) database from 1945-2018. The search has been limited to the category of WoS-CC related to agriculture, water resources, food processing, horticulture and forestry. The main research topics, areas of application and methods used were determined. In the analyzed documents, task scheduling was mainly used in irrigation and harvest scheduling. Simple and advanced optimization tools were used.
\end{abstract}

\section{Introduction}

Managing tasks is scheduling task in production management. A properly prepared schedule significantly reduces uncertainty in decision-making and ensures production stability. The complexity of production processes and the variability of factors (eg machine failures, employee absences, etc.) have a significant impact on the scheduling process [1]. In the scheduling process, Decision Support Systems (DSS) are very often used. The scheduling support module is one of the parts of the entire extended system.

Sprague and Carlson concluded "DSS comprise a class of information system that draws on transaction processing systems and interacts with the other parts of the overall information system to support the decision-making activities of managers and other knowledge workers in organizations"[2].

The major DSS sub-fields are [3]:

- Personal Decision Support Systems (PDSS)

- Group Support Systems (GSS)

- Negotiation Support Systems (NSS)

- Intelligent Decision Support Systems (IDSS)

- Knowledge Management-Based DSS (KMDSS)

* Corresponding author: adrian.knapczyk@urk.edu.pl 
- Data Warehousing (DW)

- Enterprise Reporting and Analysis Systems: enterprise focussed DSS including executive information systems (EIS), business intelligence (BI), corporate performance management systems (CPM).

DSS are used in many areas, eg production engineering, IT, transport, biosystems engineering and many others. "Biosystems Engineering is research in the physical sciences and engineering to understand, model, process or enhance biological systems for sustainable developments in agriculture, food, land use and the environment" [4]. Biosystems engineering is an important area of knowledge due to its multidisciplinarity. According to the current analysis of research trends in agricultural engineering, which is part of biosystems engineering, DSS are used in such areas as: pest management, crop production, biomass production, operational planning machine activities, and pig product chain [5].

Bibliometric analysis allows to perform objectively analyzes of publications, organizations, achievements of scientists and others. These analyzes are based on statistical quantitative analyzes of data from global scientific publication databases (Web of Science, Scopus and others). Bibliometric analysis allows to indicate trends, main research topics in a selected topic, discipline and other $[6,7]$.

\section{Aim of the study}

The aim of the work was to review DSS to support task scheduling in the field of Biosystems Engineering. To achieve the goal, the current state of research was identified and the main research topics, decision problems and methods used were identified.

\section{Materials and Methods}

A modified bibliometric analysis method proposed Knapczyk et al. [7]. The research was carried out in 5 stages:

1. Creation of a set of documents based on searching for indexed items in the Web of Science - Core Collection (WoS-CC) database for search: TOPIC: ("schedu*") AND TOPIC: ("decision support system") in Web of Science Categories: "Agricultural Economics Policy", "Agricultural Engineering", "Agriculture Dairy Animal Science", "Agriculture Multidisciplinary", "Agronomy", "Food Science Technology", "Forestry", "Plant Sciences", "Horticulture", "Veterinary Sciences", "Water Resources". The search was carried out for documents in English from 1945 to 2018.

2. Uploading all publications in the analysed period of time and extracting bibliometric data (authors, title, year of issue, key words, additional key words, publishing house).

3. Construction and analysis of term maps (VOSviewer software).

4. Quantitative analysis of the set of documents created in the aspect of: number of publications and number of citations, main research areas, major countries.

5. Thematic analysis for documents in last 10 years. The analysis of the content of documents in terms of:

- decision problem,

- area of application,

- used type of method / algorithm / framework to support scheduling

VOS viewer is a free program that is used by researchers for bibliometric analysis. In this work, the program was used to create a map of terms (years of publication). 


\section{Results}

\section{Bibliometric quantitative analysis}

In the examined period, 157 documents were analysed in total (according to WoS-CC database).

In the analysed period the main authors were: Maclean D. A. (7 documents), Hennigar C. R. (4 documents), Kinzli K. D. (4 documents), Oad R. (4 documents) and Porter K. B. (4 documents. The authors come from USA (38 documents), Spain (15 documents), Canada (14 dokuments) and China (14 documents).

The most-cited publications include:

- Tarantilis C. D. and Kiranoudis C. T. (2001) - Total Citation: 82 [8],

- Hennigar et. al. (2008) - Total Citation: 68 [9],

- MacLean D. A.et. al. (2001) - Total Citation: 67 [10],

- Vacik H. and Lexer M. J. (2001) - Total Citation: 58 [11].

In the next stage, the most frequently occurring key words were determined for the analysed periods. For each period the analysis of all key words (Author Keywords, Index Key words) was performed (VOS Viewer). Results of the simulations are presented in Fig. 1 a) b) c) d).

Fig. 1a) illustrates the relationship between key words in years. Individual colors illustrate the period of occurrence. In the period up to 2000 (dark blue), the main research topics were: „ecosystem management”, „expert systems”, „geographic information system". In the period 2000-2005 (light blue): "gis”, ,plans”, „linear programming”, „scheduling”, ,short-term”, ,stand growth”. In the period 2005-2010 (green): "modeling”, "temperature" "forest", "new-brunswick", "tabu search", "wheat", "decision support". The last period was 2010-2018 (yellow, orange, red): "decision support system", "management", “model”, “optimization", “"water management", “irrigation", “yeald", "water", "system", "water management", "climate", "evaporatranspiration", "water-use", "dssat", "soil", "phytophthora-infestans", "operation". It can be noticed that the highest intensity of keywords occurred in the last period, which proves the topicality of the subject and the great interest of scientists. Research topics have changed over the years, ranging from environmental management, through harvest scheduling both in agriculture and forestry, and ending with the management and optimization of water resources (irrigation, evapotranspiration, etc.).

In Fig. 1 b) c) d) is shown the network of links between the selected main research topic and other key words.

In Fig. 1b), it can be noticed that the "decision support system" issue covers the topics of modeling, simulation and management in the aspect of water management.

Fig.e 1c) shows the combinations of words in the aspect of "irrigation scheduling". The analysis of connections allowed to notice that DSS are used in this area for simulation, modeling, evapotranspiration and water management. DSS are used also as expert systems.

Fig. 1d) shows combinations of words in the aspect of harvest scheduling ". From the analyzes, it can be noticed that the main topics are management, planning, optimization and optimization of scheduling in the aspect of forestry. 


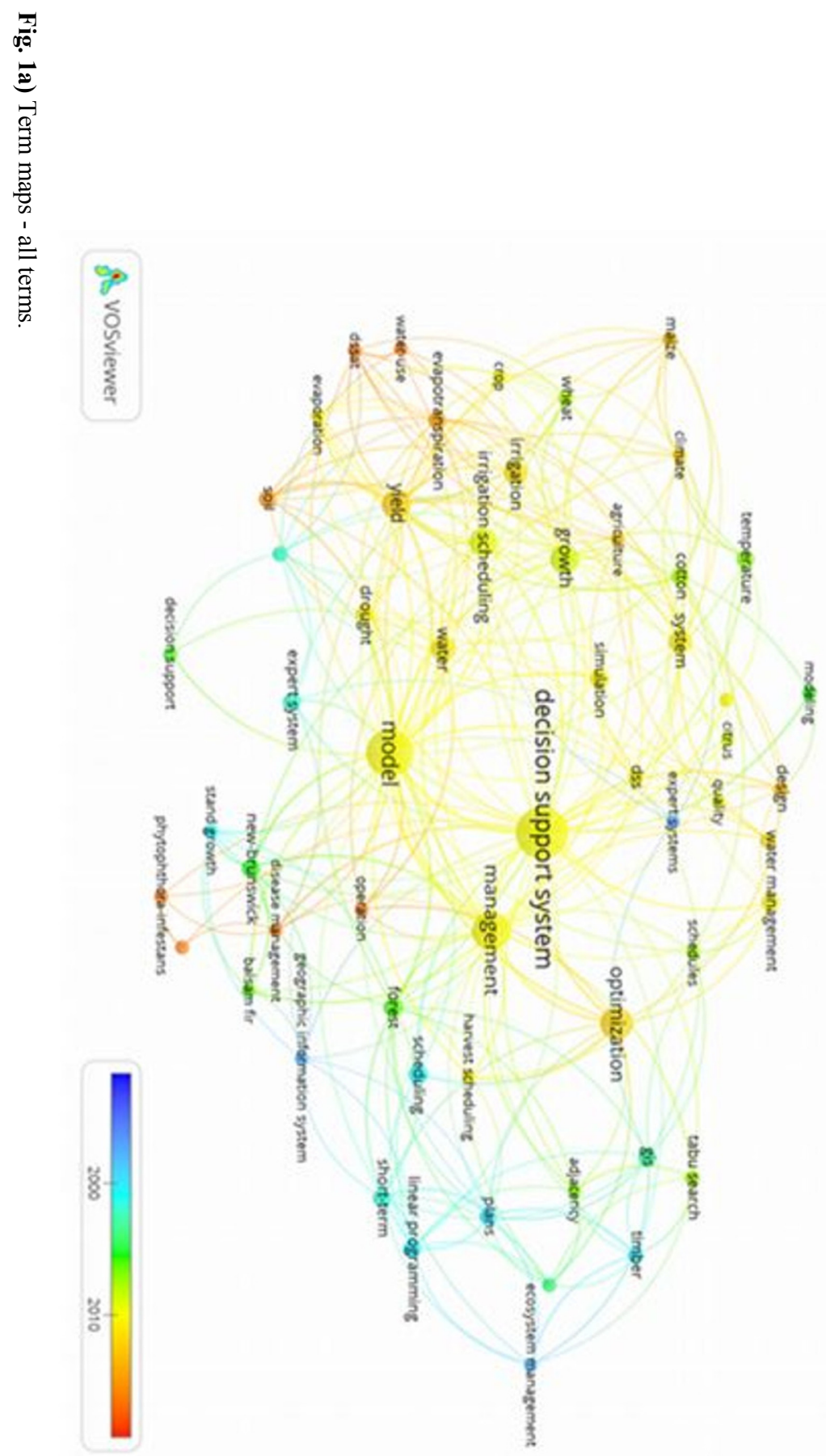




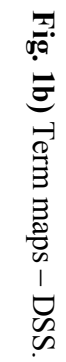
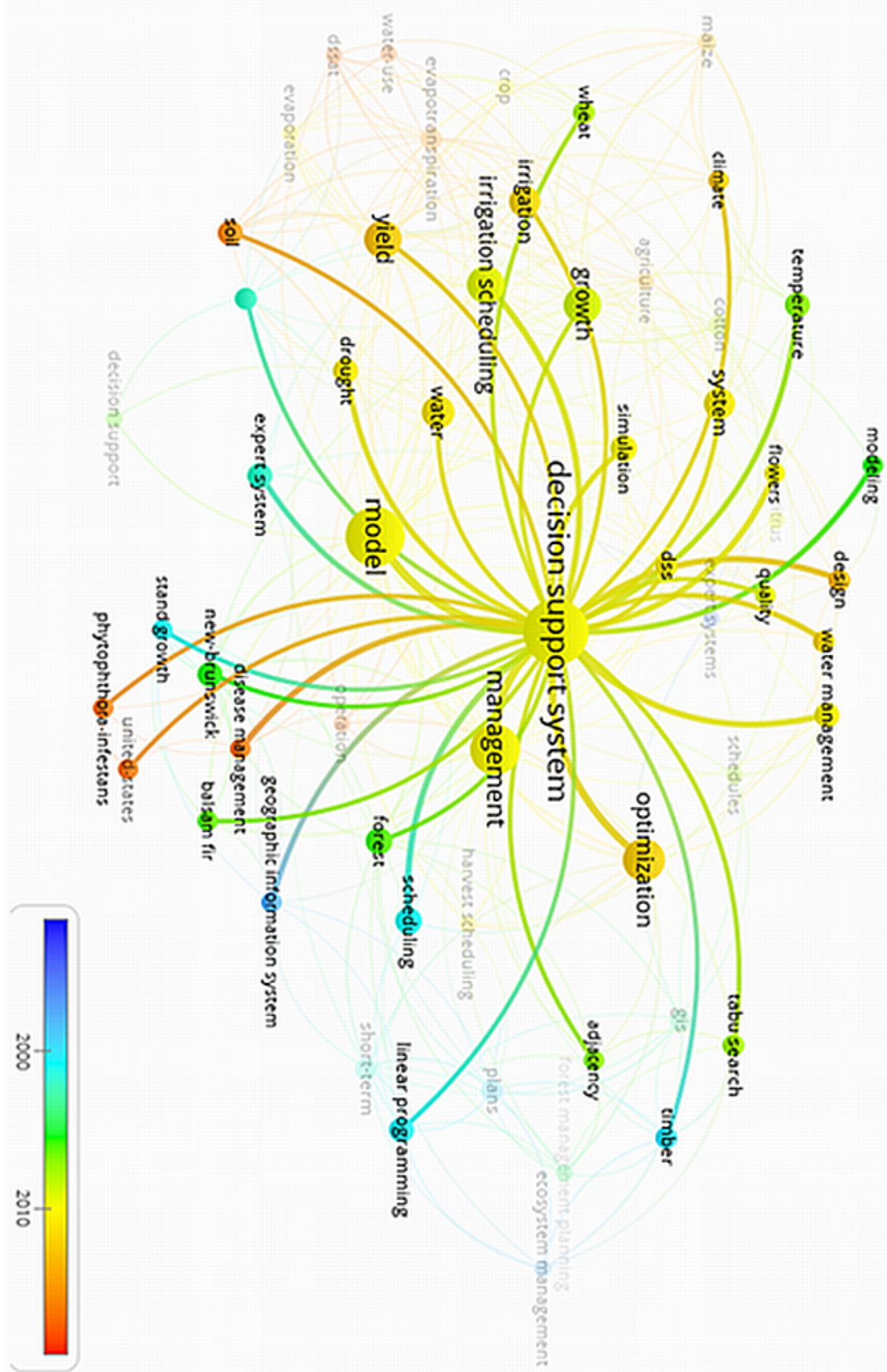
है.
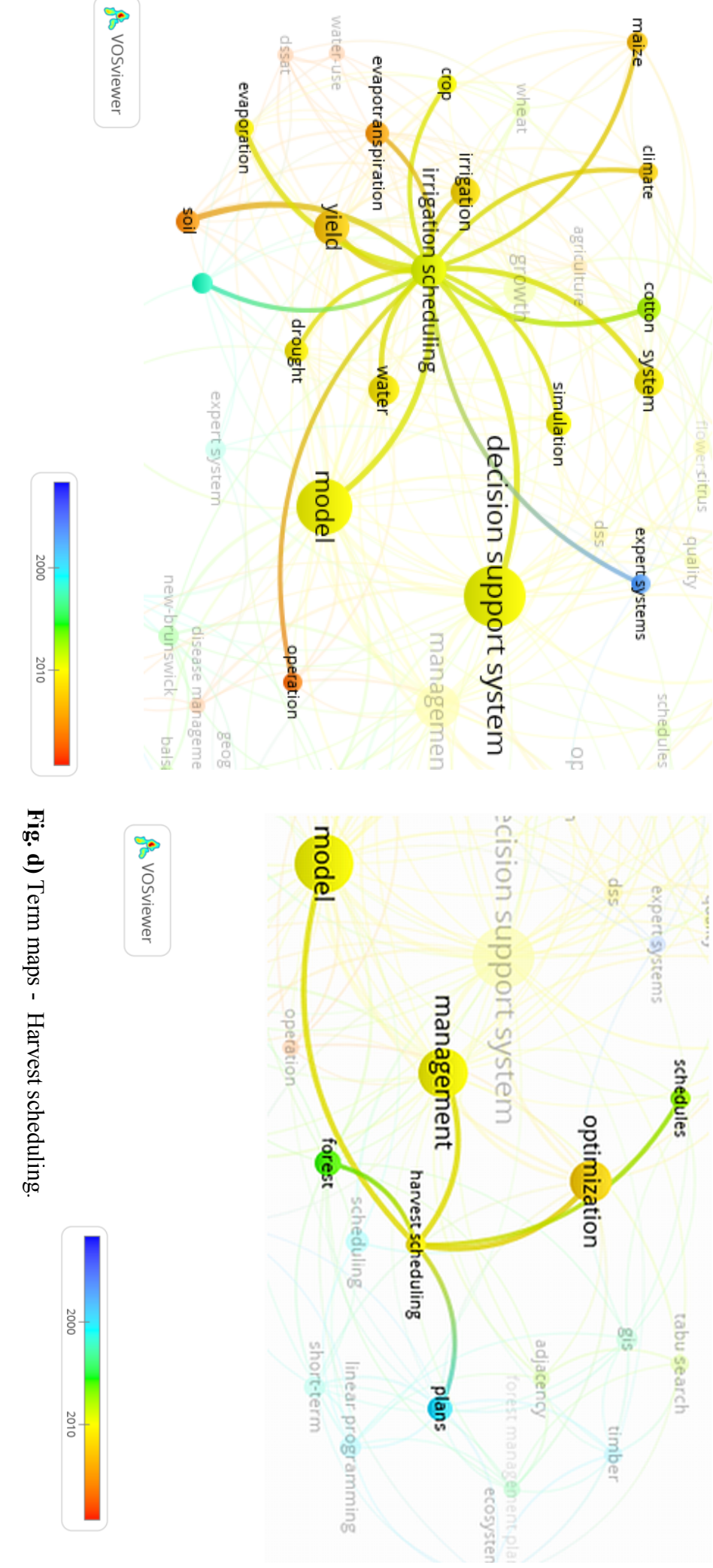


\section{Bibliometric qualitative analysis}

Thematic analysis was carried out for documents from the last 10 years. This analysis is divided into two parts: 1) harvest scheduling (Tab. 1) and 2) irrigation scheduling (Table 2). In each part, decision problems and methods / algorithms or frameworks used to solve a specific decision problem were separated.

Documents for analysis were selected by performing additional searches in the WoS-CC database for:

a) Harvest scheduling: TOPIC: „harvest schedu*”AND „decision suport system”,

b) Irrigation scheduling: TOPIC: "irrigation schedu*" AND ,decision suport system".

In the case of the first part (harvest scheduling) (Tab. 1), the issues were divided into two groups, due to the area of application, namely forestry and agriculture. As part of forestry, the main research topics related to the optimization of forest management management scheduling, the impact of excess insect reproduction and the impact of water quantity on forest productivity. Within the agricultural area, the main decisional problem was the optimization of harvest scheduling (eg tomatoes, sugar cane and grasses). Methods and systems with different levels of advancement were used in both areas. Starting from integer and mixed iteger programming, regression analysis, through simulated annealing, dynamic bayesian network, and ending with dedicated DSS.

Table 1. Main topics and methods used in harvest scheduling (2008-2018)

\begin{tabular}{|c|c|c|}
\hline $\begin{array}{l}\text { Theme } \\
\text { groups }\end{array}$ & Decision problem & $\begin{array}{l}\text { Method / algorithm / framework to } \\
\text { support scheduling }\end{array}$ \\
\hline \multirow[t]{3}{*}{ Forestry } & $\begin{array}{l}\text { - forest spatial harvest scheduling } \\
\text { problems }[12-18]\end{array}$ & $\begin{array}{l}\text { - Simulated Annealing (SA) [12] } \\
\text { - Area Restriction Model (ARM) [12] } \\
\text { - Unit Restriction Model (URM) [12] } \\
\text { - Multiple-Criteria Decision Analysis } \\
\text { (SMCDA) [13] } \\
\text { - Optimal-GIS tool [14] } \\
\text { - Integer and Mixed Integer Programming } \\
{[15,17]} \\
\text { - Ecosystem Based Multiple Use Forest } \\
\text { Management Planning Concept } \\
\text { (EBMUFM) [16] } \\
\text { - Ecosystem Based Multiple Use Forest } \\
\text { Management, ETCAPKlasik [18] }\end{array}$ \\
\hline & $\begin{array}{l}\text { - Comparison of conventional and } \\
\text { adaptive systems of cork oak tree } \\
\text { scheduling [19] }\end{array}$ & - Mixed Integer Programming [19] \\
\hline & $\begin{array}{l}\text { - The impact of excessive spread of } \\
\text { spruce budworm (SBW) outbreaks on } \\
\text { forest }[9,20]\end{array}$ & $\begin{array}{l}\text { - Spruce Budworm Decision Support } \\
\text { System [20] } \\
\text { - regression tree [9] }\end{array}$ \\
\hline
\end{tabular}




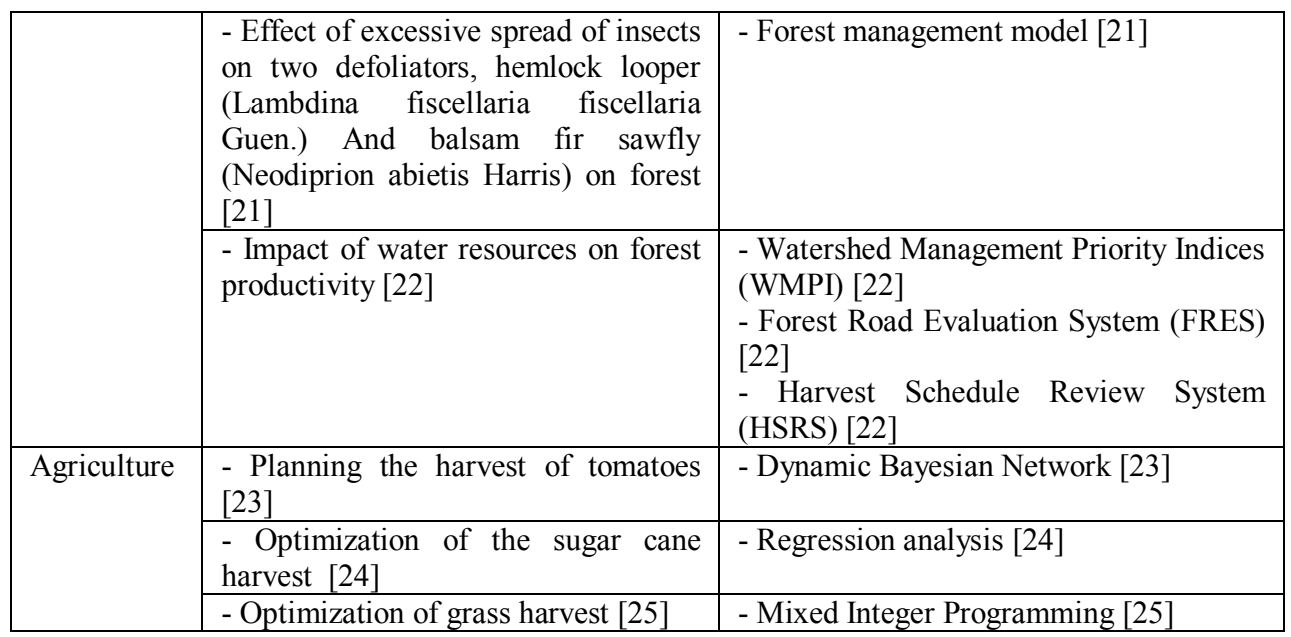

In the case of the second part (irrigation scheduling) (Tab. 2), all decision problems were related to water management in agriculture. DSS have been used at various levels and areas of application. From small irrigation systems to optimizing water management in a given country. As in the case of harvest scheduling, very diverse methods, algorithms and systems for scheduling tasks were also used here. However, predominant decision support systems prevailed.

Table 2. Main topics and methods used in irrigation scheduling (2008-2018)

\begin{tabular}{|c|c|}
\hline Decision problem & $\begin{array}{c}\text { Method / algorithm / framework to } \\
\text { support scheduling }\end{array}$ \\
\hline $\begin{array}{l}\text { - evaluate the DSS for Agrotechnology Transfer Cropping } \\
\text { System Model (DSSAT-CSM) for assessing grain sorghum } \\
\text { yield and water productivity [26] }\end{array}$ & $\begin{array}{l}\text { - DSS for Agrotechnology Transfer } \\
\text { Cropping System Model (DSSAT- } \\
\text { CSM) [26] }\end{array}$ \\
\hline - Predictive irrigation planning system $[27,28]$ & $\begin{array}{l}\text { - Artificial Neural Network (ANN) } \\
\text { [27] } \\
\text { - Predictive methods [28] }\end{array}$ \\
\hline $\begin{array}{l}\text { - Basin Irrigation Design with Multi-Criteria Analysis } \\
\text { Focusing on Water Saving and Economic Returns [29] }\end{array}$ & - (meta-)heuristics [29] \\
\hline $\begin{array}{l}\text { - A simulation tool which integrate the energy efficiency of } \\
\text { the pumping station taking into account irrigation events } \\
\text { distribution according to the crop irrigation scheduling at } \\
\text { each plot [30] }\end{array}$ & - GREDRIP [30] \\
\hline $\begin{array}{l}\text { - Quantify the effects of The El Nino Southern Oscillation } \\
\text { (ENSO) phenomenon on tomato crop water requirements } \\
\text { [31] }\end{array}$ & - AgroClimate irrigation tool [31] \\
\hline $\begin{array}{l}\text { - Development of an integrated decision support system } \\
\text { (IDSS) based on wireless sensor networks (WSN) and } \\
\text { simulation procedures [32] }\end{array}$ & $\begin{array}{l}\text { - Platform Matlab (R) i Opnet (R) } \\
\text { [32] }\end{array}$ \\
\hline $\begin{array}{l}\text { - A decision support system based on the combination of the } \\
\text { wireless sensor and actuation network technology and the } \\
\text { fuzzy logic theory [33] }\end{array}$ & - Fuzzy Logic [33] \\
\hline $\begin{array}{l}\text { - Modeling the water and nitrogen productivity of sunflower } \\
\text { using OILCROP-SUN model in Pakistan [34] }\end{array}$ & $\begin{array}{l}\text { - DSS for Agro-Technology Transfer } \\
\text { (DSSAT) [34] }\end{array}$ \\
\hline
\end{tabular}




\begin{tabular}{|c|c|}
\hline $\begin{array}{l}\text { - A flexible irrigation scheduling decision support system } \\
\text { (FIS-DSS) which could be easily customized and adapted to } \\
\text { different irrigation districts and cases, and thus repeated } \\
\text { soware development is not needed [35] }\end{array}$ & - Fuzzy Logic [35] \\
\hline $\begin{array}{l}\text { - Real time irrigation scheduling either on time basis or soil } \\
\text { moisture sensor basis [36] }\end{array}$ & - CROPWAT model [36] \\
\hline $\begin{array}{l}\text { - Efficient model-based sub-optimal irrigation scheduling } \\
\text { using imperfect weather forecasts [37] }\end{array}$ & - (meta-)heuristics [37] \\
\hline $\begin{array}{l}\text { - A scalable smart irrigation system applied to precision } \\
\text { agriculture [38] }\end{array}$ & - Fuzzy Logic [38] \\
\hline $\begin{array}{l}\text { - A simple and farmer-friendly decision support system for } \\
\text { enhancing water use efficiency in agriculture [39] }\end{array}$ & $\begin{array}{l}\text { - An Excel-based decision support } \\
\text { system termed Water Impact } \\
\text { Calculator (WIC) [39] }\end{array}$ \\
\hline - Conserve water while maintaining cotton yields [40] & $\begin{array}{l}\text { - DSS for Agrotechnology Transfer } \\
\text { (DSSAT) Cropping System Model } \\
\text { (CSM) [40] }\end{array}$ \\
\hline $\begin{array}{l}\text { - A DSS model that accurately predicts evaportranspiration } \\
\text { and can be used to schedule water delivery [41] }\end{array}$ & - (meta-)heuristics [41] \\
\hline $\begin{array}{l}\text { - Modem DSS for managing the agro-ecosystem water- } \\
\text { nutrients statuses [42] }\end{array}$ & - (meta-)heuristics [42] \\
\hline $\begin{array}{l}\text { - The realization of a monitoring Web-Based DSS } \\
\text { communicating with a Wireless Sensor Network for } \\
\text { irrigation scheduling in developing countries context [43] }\end{array}$ & - Penman-Monteith method [43] \\
\hline $\begin{array}{l}\text { - A Service Oriented Approach (SOA) used to get precise } \\
\text { irrigation schedule for mango trees [44] }\end{array}$ & - (meta-)heuristics [44] \\
\hline $\begin{array}{l}\text { - A new Web-Based DSS called AQUAMAN that was } \\
\text { developed to assist Australian peanut growers schedule } \\
\text { irrigations [45] }\end{array}$ & - System AQUAMAN [45] \\
\hline $\begin{array}{l}\text { - A soil moisture sensor-based variable rate irrigation (VRI) } \\
\text { control system was begun [46] }\end{array}$ & - (meta-)heuristics [46] \\
\hline $\begin{array}{l}\text { - Using a mobile phone Short Messaging Service (SMS) for } \\
\text { irrigation scheduling in Australia - Farmers [47] }\end{array}$ & - IrriSatSMS [47] \\
\hline $\begin{array}{l}\text { - Identifying irrigation and nitrogen best management } \\
\text { practices for sweet corn production [48] }\end{array}$ & $\begin{array}{l}\text { - DSS for Agrotechnology Transfer } \\
\text { (DSSAT), CERES-Maize model [48] }\end{array}$ \\
\hline $\begin{array}{l}\text { The DSSAT (Decision Support System for Agro- } \\
\text { Technology Transfer) model was used to determine the } \\
\text { effects of different irrigation scenarios on soil water } \\
\text { evaporation [49] }\end{array}$ & $\begin{array}{l}\text { - The DSSAT (Decision Support } \\
\text { System for Agro-Technology } \\
\text { Transfer) model [49] }\end{array}$ \\
\hline $\begin{array}{l}\text { - Simulation of maturity duration and productivity of two } \\
\text { rice varieties under system of rice intensification using } \\
\text { DSSAT v 4.5/CERES-Rice model [50] }\end{array}$ & $\begin{array}{l}\text { DSS for Agrotechnology } \\
\text { Transfer/Crop Estimation through } \\
\text { Resource and Environment Synthesis } \\
\text { (DSSAT v 4.5/CERES-Rice) model } \\
\text { [50] }\end{array}$ \\
\hline $\begin{array}{l}\text { - A knowledge-based and distributed framework that } \\
\text { simulates the behaviour of an irrigation system and permits } \\
\text { accurate determination of irrigation timing [51] }\end{array}$ & $\begin{array}{l}\text { - A Multi-Agent System Simulation } \\
\text { Platform [51] }\end{array}$ \\
\hline $\begin{array}{l}\text { - Fuzzy Logic Based DSS Framework for Irrigation } \\
\text { Scheduling [52] }\end{array}$ & - Fuzzy Logic [52] \\
\hline $\begin{array}{l}\text { - The models and the algorithms which are being used in a } \\
\text { DSS to determine water irrigation scheduling [53] }\end{array}$ & $\begin{array}{l}\text { - Supervisory Control and Data } \\
\text { Acquisition system (SCADA) [53] }\end{array}$ \\
\hline $\begin{array}{l}\text { A tool for improving agriculture sustainability and } \\
\text { adaptations to the ongoing climatic change [54] }\end{array}$ & - Irri4web [54] \\
\hline $\begin{array}{l}\text { - A farm level water management system of special value in } \\
\text { situations where the water availability and quality is limited } \\
\text { [55] }\end{array}$ & $\begin{array}{l}\text { - Universal Irrigation Scheduler, } \\
\text { Based On Crop-Water Stress Models } \\
\text { (UNIPI) [55] }\end{array}$ \\
\hline
\end{tabular}




\begin{tabular}{|c|c|}
\hline $\begin{array}{l}\text { - Contribute to sustainable irrigated agriculture by } \\
\text { developing an irrigation management system that can be } \\
\text { used for crop production in cases with limited water supply } \\
\text { and marginal water quality [56] }\end{array}$ & - MOPECO model [56] \\
\hline $\begin{array}{l}\text { - Evaluation of options for increasing yield and water } \\
\text { productivity of wheat [57] }\end{array}$ & $\begin{array}{l}\text { - The DSSAT-CSM-CERES-Wheat } \\
\text { V4.0 model [57] }\end{array}$ \\
\hline $\begin{array}{l}\text { - Perceptive research on wheat evapotranspiration in } \\
\text { Pakistan [58] }\end{array}$ & - The Mehran model [58] \\
\hline $\begin{array}{l}\text { - A methodology for helping to produce irrigation scheduling } \\
\text { policies for the deployment of water resources for } \\
\text { agricultural use [59] }\end{array}$ & $\begin{array}{l}\text { - a DSS for irrigation scheduling in } \\
\text { an arborescent network [59] }\end{array}$ \\
\hline
\end{tabular}

\section{Conclusion}

1. The analyzes show that the greatest interest of researchers in the selected topic occurred in the recent period (2010-2018) and mainly concerned management and optimization in the aspect of water management.

2. The main areas of application of DSS for scheduling tasks in biosystem engineering are harvest scheduling and irrigation scheduling.

3. In harvest scheduling, the main research topics concerned:

a) Forestry: optimization of forest management management scheduling, problems with excessive insect reproduction, impact of water quantity in the aspect of forest productivity,

b) Agriculture: optimizing harvest scheduling (eg tomatoes, sugar cane and grasses).

4. DSS irrigation scheduling has been used from small irrigation systems to optimizing water management in a given country.

5. The analyzed publications used methods, algorithms and IT systems of various advancement level. Starting from integer and mixed iteger programming, regression analysis, regression tree through simulated annealing, dynamic bayesian network, fuzzy logic, ANN and ending with dedicated decision support systems.

\section{Acknowledgements}

This research was financed by the Ministry of Science and Higher Education of the Republic of Poland (Faculty of Production and Power Engineering, University of Agriculture in Krakow).

\section{References}

1. A. Knapczyk, S. Francik, and Z. Slipek, Contemp. Res. Trends Agric. Eng. (2018).

2. R. H. Sprague and E. D. Carlson, Building Effective Decision Support Systems, Englewood Cliffs, Prentice-Hall (1982).

3. D. Arnott and G. Pervan, Decis. Support Syst. 44, 657 (2008).

4. D. Briassoulis, P. Panagakis, and E. Nikopoulos, ERABEE (2009).

5. S. Francik, A. Knapczyk, J. Frączek, and Z. Ślipek, Proc. 12th Int. Sci. Pract. Conf. 2, 44 (2019).

6. A. Knapczyk, S. Francik, N. Pedryc, and T. Hebda, 17th Int. Sci. Conf. Eng. Rural Dev. 700 (2018).

7. A. Knapczyk, S. Francik, J. Fraczek, and Z. Slipek, 18th Int. Sci. Conf. Eng. Rural 
Dev. 18, 1503 (2019).

8. C. . Tarantilis and C. . Kiranoudis, J. Food Eng. 50, 1 (2001).

9. C. Hennigar, D. MacLean, D. Quiring, and J. Kershaw, For. Sci. 54, 158 (2018).

10. D. A. MacLean, T. A. Erdle, W. E. MacKinnon, K. B. Porter, K. P. Beaton, G. Cormier, S. Morehouse, and M. Budd, Can. J. For. Res. 31, 1742 (2001).

11. H. Vacik and M. J. Lexer, For. Ecol. Manage. 143, 65 (2001).

12. L. Dong, P. Bettinger, H. Qin, and Z. Liu, Silva Fenn. 52 (2018).

13. S. Ezzati, A. Najafi, and P. Bettinger, Land use policy 59, 478 (2016).

14. R. Marušák, J. Kašpar, and P. Vopěnka, Forests 6, 163 (2015).

15. R. Marušák and J. Kašpar, Cent. Eur. For. J. 61, 71 (2015).

16. A. Kadiogullari, S. Keles, E. Baskent, and O. Bingol, KASTAMONU Univ. J. For. Fac. 15 (2015).

17. K. Öhman and L. Eriksson, Silva Fenn. 44 (2010).

18. F. Sivrikaya, E. Z. Baskent, U. Sevik, C. Akgul, A. I. Kadiogullari, and A. S. Degermenci, Environ. Eng. Manag. J. 9, 929 (2010).

19. J. H. N. Palma, J. A. Paulo, S. P. Faias, J. Garcia-Gonzalo, J. G. Borges, and M. Tomé, Reg. Environ. Chang. 15, 1569 (2015).

20. W.-Y. Chang, V. A. Lantz, C. R. Hennigar, and D. A. MacLean, Can. J. For. Res. 42, 490 (2012).

21. J. Iqbal, C. R. Hennigar, and D. A. MacLean, For. Ecol. Manage. 265, 150 (2012).

22. Y. Zhang and P. K. Barten, Environ. Model. Softw. 24, 569 (2009).

23. D. Wang, H. Zhang, and G. Yang, Intell. Autom. Soft Comput. 19, 335 (2013).

24. B. J. Stray, J. H. van Vuuren, and C. N. Bezuidenhout, Comput. Electron. Agric. 83, 21 (2012).

25. D. D. Bochtis, C. G. Sørensen, O. Green, T. Bartzanas, and S. Fountas, Biosyst. Eng. 107, 283 (2010).

26. A. Araya, I. Kisekka, P. H. Gowda, and P. V. V. Prasad, Agric. Water Manag. 203, 261 (2018).

27. O. Adeyemi, I. Grove, S. Peets, Y. Domun, and T. Norton, Sensors 18, 3408 (2018).

28. S. R. Templeton, M. Shane Perkins, H. D. Aldridge, W. C. Bridges, and B. R. Lassiter, Reg. Environ. Chang. 14, 645 (2014).

29. Q. Miao, H. Shi, J. Gonçalves, and L. Pereira, Water 10, 67 (2018).

30. F. . Lima, A. Martínez-Romero, J. M. Tarjuelo, and J. I. Córcoles, Agric. Water Manag. 210, 49 (2018).

31. E. Gelcer, C. Fraisse, L. Zotarelli, D. Perondi, H. Malia, C. Ecole, and K. Migliaccio, Water 10, 1820 (2018).

32. N. Samaras, 4th Int. Sci. Conf. Adv. Wirel. Opt. Commun. 240 (2018).

33. F. Viani, M. Bertolli, M. Salucci, and A. Polo, IEEE Sens. J. 17, 4299 (2017).

34. M. Awais, A. Wajid, W. Nasim, A. Ahmad, M. F. Saleem, M. A. Sammar Raza, M. U. Bashir, M. Habib-ur-Rahman, U. Saeed, J. Hussain, N. Arshad, and G. Hoogenboom, F. Crop. Res. 205, 67 (2017).

35. G. Yang, L. Liu, P. Guo, and M. Li, Agric. Water Manag. 179, 378 (2017).

36. J. Kumar, N. Patel, and T. Rajput, INDIAN J. Agric. Sci. 87, 648 (2017). 
37. R. Linker and G. Sylaios, Comput. Electron. Agric. 130, 118 (2016).

38. F. Viani, Microw. Opt. Technol. Lett. 58, 2186 (2016).

39. K. K. Garg, S. P. Wani, and M. D. Patil, Curr. Sci. 110, 1716 (2016).

40. N. Modala, S. Ale, N. Rajan, C. Munster, P. DeLaune, K. Thorp, S. Nair, and E. Barnes, Trans. ASABE 58, 685 (2015).

41. K.-D. Kinzli, D. Gensler, K. DeJonge, R. Oad, and N. Shafike, J. Irrig. Drain. Eng. 141, 04014067 (2015).

42. K. Gulum, E. Atasoy, I. Christov, and E. Galai, Oxid. Commun. 38, 210 (2015).

43. M. Fourati, W. Chebbi, and A. Kamoun, 3rd IEEE Int. Colloq. Inf. Sci. Technol. 37 (2014).

44. A. Nada, M. Nasr, and M. Salah, IEEE 7th Jt. Int. Inf. Technol. Artif. Intell. Conf. 409 (2014). 
45. Y. S. Chauhan, G. C. Wright, D. Holzworth, R. C. N. Rachaputi, and J. O. Payero, Irrig. Sci. 31, 271 (2013).

46. G. Vellidis, M. Tucker, C. Perry, D. Reckford, C. Butts, H. Henry, V. Liakos, R. Hill, and W. Edwards, Precis. Agric. '13 713 (2013).

47. N. J. Car, E. W. Christen, J. W. Hornbuckle, and G. A. Moore, Comput. Electron. Agric. 84, 132 (2012).

48. J. He, M. D. Dukes, G. J. Hochmuth, J. W. Jones, and W. D. Graham, Agric. Water Manag. 109, 61 (2012).

49. S. Wang, H. Li, Y. Yang, H. Wang, Y. Yang, and Y. Jia, J. FOOD Agric. Environ. 10, 911 (2012).

50. A. Dass, A. Nain, S. Sudhishri, and S. Chandra, J. Agrometeorol. 14, 26 (2012).

51. D. Isern, S. Abelló, and A. Moreno, Comput. Electron. Agric. 87, 1 (2012).

52. J. Patel, H. Patel, and C. Bhatt, 3rd Nirma-University Int. Conf. Eng. (2012).

53. M. Almiñana, L. F. Escudero, M. Landete, J. F. Monge, A. Rabasa, and J. SánchezSoriano, OMEGA-INTERNATIONAL J. Manag. Sci. 38, 492 (2010).

54. F. Zottele, G. Toller, and E. Eccel, Ital. J. Agrometeorol. Ital. DI Agrometeorol. 15, 5 (2010).

55. A. Anastasiou, D. Savvas, G. Pasgianos, N. Sigrimis, C. Stangellini, and F. Kempkes, Int. Symp. Strateg. Towar. Sustain. Prot. Cultiv. MILD WINTER Clim. 253 (2009).

56. J. Balendonck, C. Stanghellini, J. Hemming, F. Kempkes, and B. Van Tuijl, Int. Symp. Strateg. Towar. Sustain. Prot. Cultiv. Mild Winter Clim. 247 (2009).

57. J. Timsina, D. Godwin, E. Humphreys, Yadvinder-Singh, Bijay-Singh, S. S. Kukal, and D. Smith, Agric. Water Manag. 95, 1099 (2008).

58. K. Q. Laghari, B. K. Lashari, and H. M. Memon, Irrig. Drain. 57, 571 (2008).

59. A. Alminana, L. Escudero, M. Landete, J. Monge, A. Rabasa, and J. Sanchez-Soriano, 2nd Conf. Sustain. Irrig. Manag. Technol. Policies 112, 255 (2008). 